\title{
REVISTA QUAESTIO IURIS
}

\section{Editorial para o vol. 11-4 (2018)}

A Revista Quaestio Iuris, indexada na Web of Science, de periodicidade trimestral, nesse volume 11, número 04,2018 , tem o prazer de informar a todos os seus leitores que foi classificada entre as revistas estrangeiras mais bem avaliadas da Scholarly Publishers Indicators in Humanities and Social Sciences, Espanha, com ICEE de 8.000. A Scholarly Publishers Indicators - SPI é um sistema de informações que oferece indicadores e ferramentas relacionados com editores, revistas científicas ou de interesse para a investigação no âmbito das humanidades e das ciências sociais. Em sua origem, foi criado como um dos resultados do projeto de investigação "Categorización de publicaciones científicas en Ciencias Humanas y Sociales", financiado pelo CSIC. Agora, graças à investigação desenvolvida no projeto do Plano Nacional de $\mathrm{I}+\mathrm{D}+\mathrm{i}$, "Evaluación de editoriales científicas (españolas y extranjeras) de libros en Ciencias Humanas y Sociales a través de la opinión de los expertos y del análisis de los procesos editoriales", Espanha, o sistema pode crescer. Os indicadores que se incluem no SPI pretendem servir como referência nos processos de avaliação de revistas científicas e permitir a objetivação de alguns conceitos como o de prestígio da revista científica.

A Revista tem ainda o prazer de publicar o artigo "Reflexiones sobre el reformismo y la obesidad constitucional en México. De la costumbre institucional a la realidad cultural”, de Ramón Gil Carreón Gallegos, profesor catedrático da Universidade Juárez do Estado de Durango e Magistrado do Tribunal Superior de Justicia de Durango, México.

No artigo "Reflexiones sobre el reformismo y la obesidad constitucional en México. De la costumbre institucional a la realidad cultural analisam-se as múltiplas reformas da Constituição mexicana, que refletem uma excessiva atividade reformista dos legisladores, assim como o grande aumento do conteúdo da Constituição desde a sua aprovação no ano de 1971. O aumento enorme de seus conteúdos, assim como a constante reforma da Constituição, não se refletiu em uma cultura de legalidade, ao contrário, na atualidade existe um desconhecimento geral do texto constitucional mexicano, além de que existem sérios problemas no país que importam em uma crise do Estado, da Constituição e dos direitos humanos. Pretende-se mostrar que o aumento desmedido dos conteúdos da Constituição mexicana não são o caminho adequado para consolidar o Estado de direito mexicano.

Da mesma maneira que nos números anteriores, no presente volume 11, número 04,2018 , publicamos 33 (trinta e três) artigos inéditos, sendo 05 (cinco) artigos estrangeiros: o já citado Reflexiones sobre el reformismo y la obesidad constitucional en México. De la costumbre institucional a la realidad cultural, de 
Ramón Gil Carreón Gallegos, profesor catedrático da Universidade Juárez do Estado de Durango, México, e Magistrado do Segundo Seminário da Câmara Civil Colegiada do Superior Tribunal de Justiça de Durango, México; La historia clínica como prueba para la responsabilidad civil por mala práctica médica, de Beatriz Gallegos Pérez, Doutoranda em Estudos Jurídicos pela Universidade Juárez Autônoma de Tabasco, México; La autonomía progresiva de la voluntad y el interés superior de la niñez: principios que impactan el sistema jurídico mexicano, de Yesenia Guadalupe Crespo, Doutora em Direito, Pesquisadora em período integral, professor titular da Universidade Juárez Autônoma de Tabasco, México; Los gastos tributarios y las exenciones para las cooperativas en Costa Rica y México, de Graciela Lara Gómez, Doutora em Estudos Organizacionais pela Universidade Metropolitana Autônoma, Professora Pesquisadora da Universidade Autônoma de Querétaro, México e The identification of religious genocide with emphasis on genocide of Shiites, de Mohammad Jamadi, Doutorando em Direito Internacional Geral, Ramo Isfahan, Universidade Islâmica Azad, Isfahan, Irã.

Nesse número publicamos também o Dossiê Amazônia: o sistema de direitos e o desenvolvimento da justiça na Amazônia Ocidental, sob a coordenação dos Professores da Universidade Federal de Rondônia UNIR, Rodolfo de Freitas Jacarandá e Delson Fernando Barcellos Xavier, com 06 (seis) artigos, a saber: Hidrelétricas do rio Madeira e o acesso à justiça; As particularidades jurídicas da ocupação do espaço urbano da capital de um jovem ex-território na Amazônia Ocidental: violações de direitos humanos e resistência; A violência como instrumentos de poder nas relações sociais e como instrumentos de dominação; A invalidade da reputação ilibada e da idoneidade moral: reflexões decoloniais; Crimes verdes e colarinho branco: a máfia da madeira na Amazônia Ocidental, uma violação aos direitos humanos; $\mathrm{O}$ aprimoramento das instituições como garantia do efetivo acesso à justiça e Metas do Conselho Nacional de Justiça e o direito responsivo: uma análise no Tribunal de Justiça do Estado de Rondônia.

Publicamos também em nossa Seção Monografias um estudo denominado O jurisprudencialismo de António Castanheira Neves e o funcionalismo jurídico, de Ivan Cláudio Pereira Borges, Doutor em Direito pelo Instituto CEUB de Pesquisa e Desenvolvimento e Professor do Centro de Ensino Universitário de Brasília UNICEUB, Brasília.

Em nossa Seção Ensaios publicamos 15 (quinze) ensaios, sendo 06 (seis) ensaios sobre direitos fundamentais: A ressignificação da democracia diante da(s) crise(s) do Estado: um novo caminho frente à racionalidade neoliberal; Delimitando o ativismo judicial: acepções, críticas e conceitos; Os deveres fundamentais e a desobediência civil em democracias de baixíssima intensidade: aproximações e distanciamentos a partir da ilegitimidade de um governo; Suspeitos? Narrativas e expectativas de jovens negros e negras e policiais militares sobre a abordagem policial e a discriminação racial em Brasília, Salvador e Curitiba; O direito ao trabalho achado na rua: o despertar da sociedade e as transformações substantivas requeridas pelo mundo do trabalho e pelo 
Estado democrático de direito e Diálogo de Cortes: a influência da Corte Interamericana de Direitos Humanos em matéria de execução penal no Supremo Tribunal Federal.

Nesse número da Revista mantivemos nosso corpo de nossos pareceristas/avaliadores, de inúmeros Estados do país e professores estrangeiros, em um total de mais de 650 (seiscentos e cinquenta) pareceristas avaliadores. Publicamos ainda, para consulta imediata dos leitores, os links dos diversos indexadores nacionais e internacionais de Revistas e periódicos onde nossa Revista Quaestio Iuris está indexada. Agradecemos, como sempre, a todos os leitores, autores, avaliadores e colaboradores pela colaboração e confiança e pelo sempre excelente trabalho realizado. Lembramos sempre que as submissões para a Revista Quaestio Iuris são permanentes e devem ser realizadas pelo sistema, diretamente na página da Revista.

Boa leitura a todos!

Mauricio Mota

Editor da Revista Quaestio Iuris 